\title{
Litígios transfronteiriços na região das Guianas: questões geopolíticas na interface entre a Amazônia e o Caribe*
}

\section{Gutemberg de Vilhena Silva}

\section{Introdução}

A parte setentrional da América do Sul, principalmente a que constitui a região das Guianas, entre os rios Orenoco e Amazonas, é um aglomerado pouco conhecido e estudado. Encontramos ali os únicos territórios sulamericanos que não foram colônias ibéricas: as "3 Guianas" (República Cooperativa da Guiana, Suriname e Guiana Francesa), que constituem também uma verdadeira interface entre os mundos amazônico e caribenho. As Guianas são amazônicas por seus ecossistemas, mas cultural e historicamente caribenhos. Esta região tem, com efeito, uma extensão continental de economias de plantations de expressão colonial europeia baseada na escravidão de populações originárias da África. (TAGLIONI; CRUSE, 2011).

No curso de três zonas estratégicas (Amazônia, Caribe e Europa), esta região se caracteriza igualmente pela presença abundante de recursos minerais, o que contribui para numerosas reivindicações marítimo-territoriais que são frequentemente consequência da presença de matérias primas estratégicas como petróleo e ouro. De fato, podemos afirmar que esta região é uma das várias que conheceu a maior parte das contestações fronteiriças sobre o continente americano. Estas contestações são reivindicações mutuas provocadas por uma herança de antigos equívocos de medidas topográficas e cartográficas e de interesses econômicos conflituosos contemporâneos, implicando Estados nacionais, mas também empresas transnacionais.

Nosso objetivo neste texto é analisar a origem e a atualidade de litígios na região das Guianas e como os recursos naturais nas suas zonas fronteiriças ainda mal conhecidas constituem elementos em destaque contra a resolução de tais litígios. A metodologia deste trabalho foi fundada sobre análise documental e bibliográfica, além de atualização de cartografia temática, mas também tendo no trabalho de campo uma base fundamental. Nós nos concentraremos inicialmente nas questões concernentes às

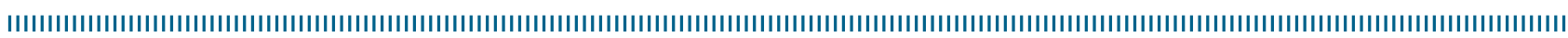
Como citar este artigo:

SILVA, Gutemberg de Vilhena. "Litígios transfronteiriços na região das Guianas: questões geopolíticas na interface entre a Amazônia e o Caribe”. In: RÜCKERT, A. A.; SILVA, A. C. P. da; SILVA, G. de V. (Orgs.). Geografia Política, Geopolítica e Gestão do Território: integração sul-americana e regiões periféricas. Porto Alegre: Editora Letra1, 2018, p. 199-217 DOI 10.21507/9788563800367-12 
reivindicações territoriais e, em seguida, avaliar os litígios marítimos.

\section{Quadro conceitual e geográfico: a região das guianas e a noção de "reivindicação territorial"}

\section{A região das Guianas}

Situada no norte-nordeste da América do Sul, a região das Guianas (Mapa 1) é um complexo histórico-geopolítico com mais de 3 milhões de anos encravado de uma parte e da outra da linha do Equador e margeada pelo oceano Atlântico ao nordeste, e os rios Orenoco a oeste e o Amazonas ao sul. Com uma superfície de mais de 1,5 milhões de $\mathrm{Km}^{2}$, a região é dividida entre 5 Estados: Venezuela (estados de Bolívar e Amazonas) e o Brasil (estados do Amapá, Roraima e partes do Pará e Amazonas) em parte, e a totalidade da Rep. da Guiana (ex Guiana Britânica), o Suriname (ex Guiana Holandeza), e a França (através da Coletividade Territorial da Guiana Francesa).

Este espaço compreende no mundo amazônico o maior conjunto de floresta tropical primária continua e intacta do mundo. Constitui também uma zona geográfica com forte potencial ecológico na luta contra as mudanças climáticas, em razão de sua enorme capacidade de captar o dióxido de carbono $\left(\mathrm{CO}_{2}\right)$. Contém perto de $15 \%$ das reservas de água doce do mundo e constitui uma zona extremamente rica em biodiversidade (fauna e flora), em que parte desta riqueza se encontra apenas nesta região. Além disso, a região é habitada por comunidades indígenas que dependem de bens e serviços ambientais permitidos pelos ecossistemas locais, tais como água, alimentos e medicamentos. (PNUD, 2014).

Esta área também é rica em recursos naturais, incluindo petróleo, ouro e diamantes, mas também alumínio, bauxita, manganês, ferro, cobre e níquel. Apesar desta riqueza, o padrão de vida da população local, com exceção da parte francesa, é baixo (ver Tabela 1).

O ambiente econômico pouco favorável da região estimulou a produção e a comercialização de drogas ilícitas, extração ilegal de minerais e a exploração de madeira sem qualquer controle técnico - e, claro, sem levar em conta a sustentabilidade dos recursos. Estas atividades econômicas informais causaram um aumento da pressão sobre os ecossistemas da região e sobre a sociedade e a economia dos Estados concernentes. (PNUD, 2014). No entanto, embora estes problemas sejam importantes para reflexões, nosso trabalho será limitado às disputas fronteiriças na região.

A extensão territorial dos cinco estados da região, cerca de $170000 \mathrm{~km}$ e mais de $36000 \mathrm{~km}$ de plataforma continental ${ }^{1}$, são ainda objeto de reivindicações não resolvidas na região das Guianas (Tabela 2). As demarcações dos limites remontam o período colonial e foram normalmente feitas com base na teoria das "fronteiras naturais". Neste caso, os rios - principais vias de comunicação nessas áreas florestais -constituíram um limite fácil de visualizar, por isso eles foram arbitrariamente escolhidos como limites inter-imperiais em termos de relações de poder coloniais, como bem expôs Foucher (1988), enquanto que para as populações indígenas autóctones estes rios foram acima de tudo os canais de comunicação. (LÉZY 2000).

\section{As Fronteiras internacionais e suas contestações nas Guianas}

A multiplicidade de atores (os nativos americanos, colonizadores, noir-marrons, populações fronteiriças, comunidades religiosas, militares, empresas nacionais e transnacionais,

\section{IIIIIIIIIIIIIIIIIIIIIIIIIIIIIIIIIII}

1 A plataforma continental de um Estado costeiro compreende o leito e o subsolo das áreas submarinas que se estendem além do seu mar territorial, em toda a extensão do prolongamento natural do seu território terrestre até ao bordo exterior da margem continental, ou até uma distância de 200 milhas marítimas das linhas de base, a partir das quais se mede a largura do mar territorial, nos casos em que o bordo exterior da margem continental não atinja essa distância (ONU, 1982, Art. 76). Para Souza (1999), a definição de plataforma continental tem um enfoque jurídico (PCJ) e pouco tem a ver com o conceito fisiográfico ou geomorfológico de plataforma continental (PCG). Pela definição jurídica de plataforma continental, vemos que a PCJ de um Estado costeiro pode englobar as feições fisiográficas conhecidas como plataforma, talude e elevação continentais, e, em algumas circunstâncias, inclusive regiões da planície abissal. 
Mapa 1. Localização da região das Guianas.

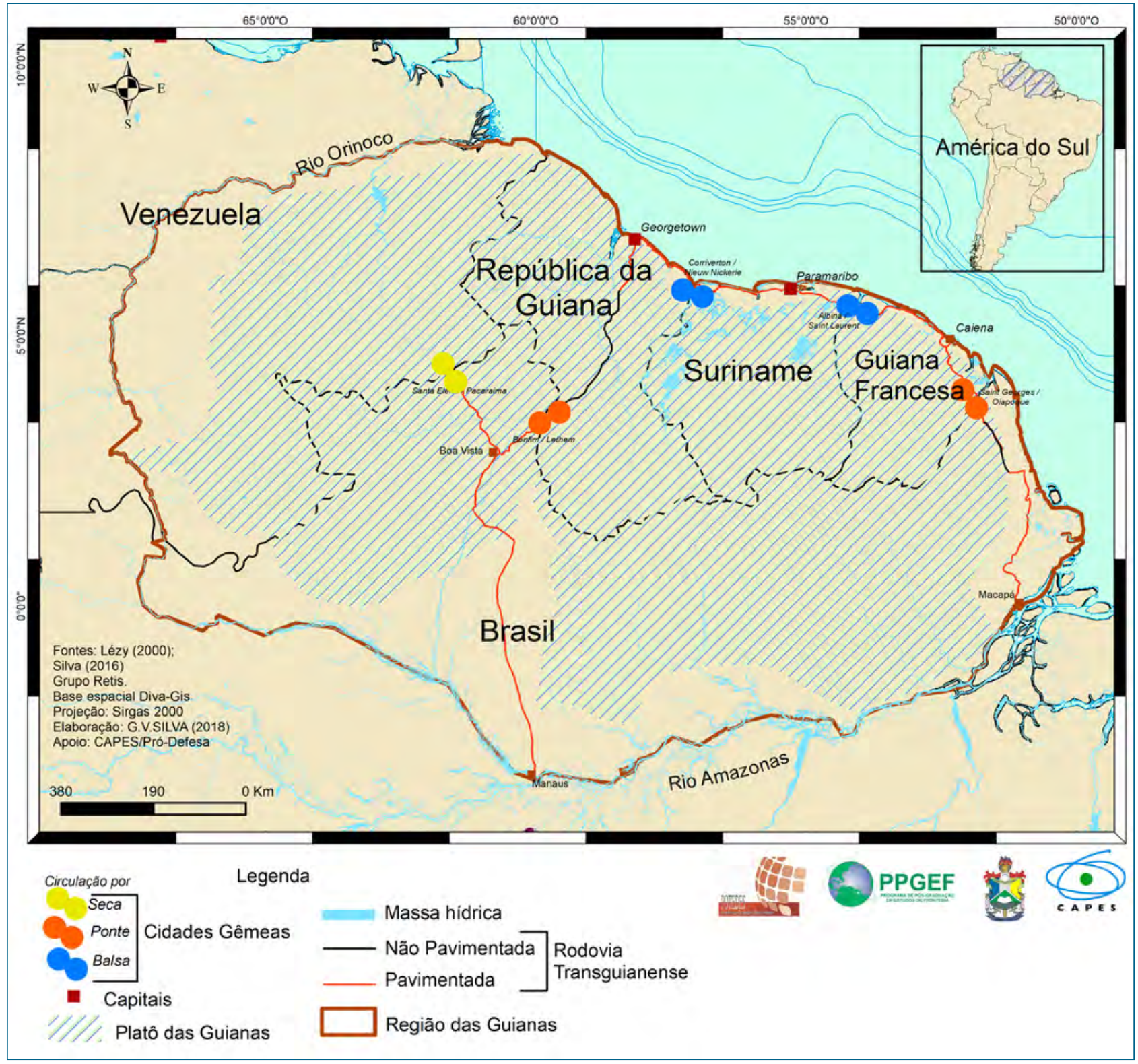

etc.) e seus antagonismos nas Guianas, particularmente em suas zonas fronteiriças, levaram a um questionamento constante em relação às demarcações, muitas das quais nunca foram aceitas por uma das partes, ou se aceitas inicialmente foram depois de um tempo questionadas em alguns casos.

A distância relativa e muitas vezes a pouca acessibilidade destas regiões fronteiriças são pontos cegos em relação a suas respectivas áreas nacionais, pela sua baixa taxa demográfica e pelo afastamento dos centros de poder ou de produção. (SANGUIN, 2007). As reivindicações constituem, assim, potenciais obstáculos ao exercício da soberania desses Estados, de tal modo que eles podem dar origem a disputas ou reclamações por estados vizinhos, como tinham entendido os geopolíticos brasileiros dos anos 1960-1970, que visavam a integração física e econômica das margens amazônicas para evitar qualquer tipo de separação. (MIYAMOTO, 1981).

A determinação e a consolidação das fronteiras internacionais passam por três etapas. Em primeiro lugar a definição, permitido pelos tratados internacionais. A formalização de limites precede o exercício da soberania que é expressa em termos 
Tabela 1. Renda per capita (América do Sul, França e Guiana Francesa, em USD).

\begin{tabular}{lccc}
\hline País & Ano 2015 & Posição na América do Sul & Mundo* \\
\hline Chile & 23.460 & 1 & 54 \\
Argentina & 22.554 & 2 & 55 \\
Uruguai & 21.507 & 3 & 58 \\
Guiana Francesa** & 20.851 & 4 & - \\
Venezuela & 16.673 & 5 & 69 \\
Suriname & 16.292 & 6 & 73 \\
Brasil & 15.615 & 7 & 76 \\
Colômbia & 13.847 & 8 & 86 \\
Peru & 12.195 & 9 & 90 \\
Equador & 11.264 & 10 & 98 \\
Paraguai & 8.708 & 11 & 107 \\
Rep. Guiana & 7.509 & 12 & 116 \\
Bolívia & 6.465 & 13 & 121 \\
França & 41.181 & 14 & 24 \\
\hline
\end{tabular}

*A classificação integra 185 Estados; ${ }^{* *}$ Dados de 2013

Fonte: World Economic Outlook Database. Fundo Monetário Internacional. Consultado em 23 de janeiro de 2017.

Tabela 2. Dados dos Estados do Platô das Guianas com disputas territoriais.

\begin{tabular}{|c|c|c|c|c|c|}
\hline Informações & $\begin{array}{c}\text { Venezuela (Estados } \\
\text { de Bolivar e } \\
\text { Amazonas) }\end{array}$ & Guyana & Suriname & $\begin{array}{c}\text { Guiana Francesa } \\
\text { (França) }\end{array}$ & Total \\
\hline Capitais & Caracas & Georgetown & Paramaribo & Cayenne & --- \\
\hline População total (2016) & 31925705 & 770610 & 547610 & 275688 & 33519613 \\
\hline \% População urbana & $88,5 \%$ & $30,2 \%$ & $66,6 \%$ & $82,3 \%$ & 66,90\% (média) \\
\hline $\begin{array}{l}\text { População do Platô das } \\
\text { Guianas (2011) }\end{array}$ & 1725120 & 747884 & 541638 & 239849 & 3254491 \\
\hline Superfícies $\left(\mathrm{km}^{2}\right)$ & 916445 & 214999 & 163820 & 83534 & 1379445 \\
\hline $\begin{array}{l}\text { Extensão dos limites } \\
\text { territoriais no Platô das } \\
\text { Guianas }(\mathrm{km})\end{array}$ & $\begin{array}{l}\text { Com o Brasil 2.199; } \\
\text { com a Rep. da } \\
\text { Guiana } 743\end{array}$ & $\begin{array}{l}\text { Com o Brasil } 1.606 \text {; com a } \\
\text { Venezuela } 743 ; \text { com o Suriname } \\
600\end{array}$ & $\begin{array}{l}\text { Com o Brasil 593; } \\
\text { com a Rep. da Guiana } \\
600 \text {; Com a Guiane } \\
\text { Francesa } 510\end{array}$ & $\begin{array}{l}\text { Com o Brasil } 730 ; \text { com } \\
\text { o Suriname } 510\end{array}$ & 6981 \\
\hline $\begin{array}{l}\text { Superficie dos territórios } \\
\text { reivindicados }\left(\mathrm{km}^{2}\right)\end{array}$ & $\begin{array}{l}\text { Essequibo : } \\
159500 \mathrm{~km}^{2}\end{array}$ & 0 & 11000 & approx. 5000 & 170500 \\
\hline $\begin{array}{l}\text { Superficie dos espaços } \\
\text { marítimos contestados }\end{array}$ & -- & 36000 & 36000 & -- & 64000 \\
\hline $\begin{array}{l}\text { Recursos naturais nas } \\
\text { regiões reivindicadas }\end{array}$ & Petróleo & $\begin{array}{l}\text { Petróleo (Mar do Caribe) ; ouro, } \\
\text { ferro, cobre, manganês, niquel, } \\
\text { mica (Essequibo) ; alumínio, } \\
\text { bauxita, ouro e provavelmente } \\
\text { diamante (TNR) }\end{array}$ & $\begin{array}{l}\text { Petróleo, Ouro, } \\
\text { Bauxita }\end{array}$ & Ouro & --- \\
\hline
\end{tabular}

Fontes: Ramjad (2002) ; Donavan (2003) ; Domínguez et al. (2003) ; Egger (2009) ; Statistics Guyana ; INE, Venezuela ; Algemeen Bureau voor de Statistiek, Suriname ; INSEE, Recensemeamento da população: <http://www.geohive.com/entry/guyana.aspx>; $\langle$ http ://www.geohive/entry/venezuela.aspx >; <http ://www.geohive.com/entry/suriname.aspx>; 〈http://www.worldometers.info/ population/countries-in-latin-america-and-the-caribbean-by-population/>. Organização própria.

militares, jurídicos, burocráticos, econômicas e ideológicas. (GUICHONNET; RAFFESTIN, 1974). Mas a área de ação do Estado, raramente uniforme, implica uma delimitação, a cargo de cartógrafos e uma demarcação, a partir da qual os Estados envolvidos saberão exatamente os limites de seu território terrestre.
A posição das fronteiras terrestres tem um impacto direto sobre as fronteiras marítimas. Assim, a ligação entre as fronteiras terrestres e marítimas complexificam as negociações para as suas correspondentes demarcações. (HOYLE, 2001). Nas Guianas, tais são os casos da relação ainda problemática entre limites internos 
(territoriais) e externos (marítimos) da Rep. da Guiana, e do Suriname. O Brasil, por seu turno, resolveu todas as suas disputas territoriais há bastante tempo. (VAN LIER, 2005; MENCK, 2009; SILVA, 2013ab).

A reivindicação marítimo-territorial, concepção central neste texto, é entendida como a vontade de um Estado de recuperar uma porção do espaço, seja na terra ou no mar, à custa de outro Estado, seguindo as delimitações não aceitas. As reivindicações nas Guianas envolvem quatro países: Venezuela, Rep. da Guiana, Suriname e França (este último através da Guiana Francesa) e cobrem uma população de mais de 3 milhões de habitantes $(10,68 \%$ da população total de estes territórios 4, ver Tabela 2 ).

Estados envolvidos em tais litígios não estão em guerra uns contra os outros e procuram resolver as suas disputas sem recorrer a um conflito militarizado. (HENSEL; TURES, 1997). É esta a configuração que caracteriza as reivindicações ainda não resolvidas nas Guianas. Estas reivindicações têm origem em dificuldades técnicas e logísticas para percorrer a densa floresta amazônica pelo menos até o século XX. As tensões na região envolveram Portugal, Espanha, França, Holanda e Grã-Bretanha, ou seja, todos os países que participaram na colonização das Américas. Assim, encontramos uma grande parte das Guianas, com exceção da Venezuela e do Brasil, os únicos países da América do Sul cuja língua oficial não é nem Português nem Espanhol, mas o Inglês (Guiana), o Holandês (Suriname) e o francês (Guiana Francesa).

Por um longo tempo, disputas territoriais foram tratadas diretamente entre os colonizadores, mas sem que estes chegassem a um acordo final sobre as suas fronteiras internacionais. Autores como Akehurst (1987) e Levi (1991, citado por HENSEL; TURES (1997) mostraram que a maioria das disputas interestatais foi resolvida por negociações diretas entre as partes sem a ajuda de terceiros. No entanto, como veremos no caso de litígio entre a Venezuela e a Rep. da Guiana, e entre esta e Suriname, a ausência de intervenção externa nas negociações bilaterais impediu por muito tempo uma solução mutuamente aceitável e perene.

A abundância de recursos naturais nas áreas disputadas e o nível relativamente baixo do desenvolvimento humano, explicam a importância dos motivos econômicos em litígios contemporâneos. Analisaremos estas reivindicações marítimo-territoriais sobre a região das Guianas (Mapa 2) a partir da geopolítica e da geo-história como fio condutor. Sob o ângulo geopolítico, vamos avaliar as estratégias e principais motivações da relação entre espaço e poder. (BECKER, 2005; DUSSOUY, 2010; GABRIEL OYHAMBURU, 2010). Em termos de geo-história, vamos rever as etapas e trajetórias que levaram à atual configuração territorial dos litígios em questão. (BRAUDEL, 1997; JACOB ROUSSEAU, 2009).

\section{As reivindicações territoriais}

\section{O caso de Essequibo}

A Venezuela argumenta que o limite "natural" dela com a Rep. da Guiana é formado pelo rio Essequibo e não a linha Schomburgk² (Mapa 2), traçada em 1844 e apresentada em 1886 pelo Reino Unido como a fronteira internacional. Em 1899, a arbitragem dos Estados Unidos gerou concessões bilaterais permitindo delimitações feitas em 1905 (CABRERA SIFONTES, 1970; PAÚL, 1983; 2005; DONAVAN, 2003; MARTÍNEZ, 2011), mas subtraindo da Venezuela um território de $160000 \mathrm{~km} 2$ e mais de $200 \mathrm{~km}$ de costas no Oceano Atlântico, o que trouxe conseqüências mais tarde do ponto de vista do direito marítimo e de exploração de recursos. (POUYLLAU, 1982). O território perdido e depois reivindicado pertencia à Capitania Geral da Venezuela antes da independência do país em 19 de abril de 1810, que foi seguido por mudanças decorrentes de tratados e relatórios de arbitragem internacionais. (HENSEL; TURES, 1997; VENEZUELA, 2010).

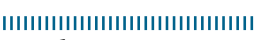

2 Robert Hermann Schomburgk nasceu em Freiburg (Alemanha), mas serviu à Coroa Britânica como oficial para fixar suas fronteiras. A definição dos limites internacionais com a Venezuela ficou conhecida por linha Schomburgk. 
Mapa 2. Os litígios na região das Guianas.

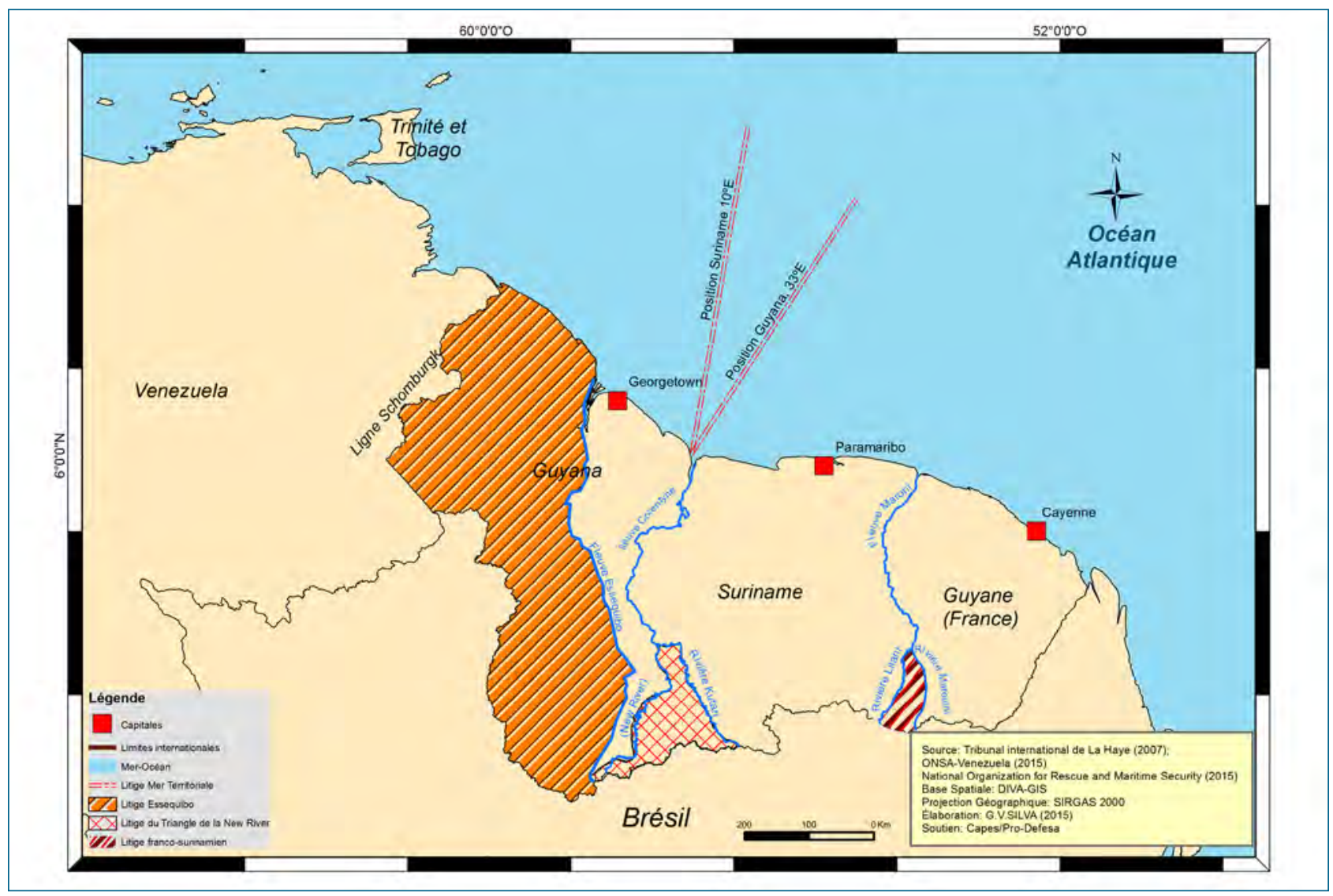

Em 1954, na X Conferência Interamericana realizada em Caracas, a Venezuela reviveu sua reivindicação por Essequibo, considerando nula a sentença arbitral de 1899. Certamente, as reivindicações da Venezuela já haviam ocorrido antes dessa data, mas, a partir desse momento, por razões econômicas relacionadas à descoberta das reservas de petróleo, a disputa tomou um novo e complexo rumo. Em 1968, o governo venezuelano decidiu, por decreto, exercer a sua soberania marítima de 9 milhas de águas territoriais, de acordo com as leis da época, para a linha formada pelo rio Essequibo (CAIRO CAROU; LOIS, 2014) incorporando, pelo menos no decreto, quase metade da Rep. da Guiana. Em 1970, embora tenha ocupado a Ilha de Anacoco, até então guianense, a Venezuela assinou um tratado com o Reino Unido em que se comprometia em respeitar a independência e a integridade territorial da Rep. da Guiana, que ocorreu em 1966. No entanto, apesar da assinatura, a Venezuela ainda afirmava seu controle sobre o Essequibo.

De fato, as relações tinham mudado com a independência da até então Guiana britânica. Não se tratava mais de uma potência imperialista (Reino Unido) rivalizando contra a Venezuela, mas de um jovem Estado com muitos desafios políticos e econômicos a serem superados (POUYLLAU, 1982).

A região de Essequibo é pouco povoada, com 107500 habitantes dos 747000 do país (Tabela 2). A maioria dos habitantes trabalha com minérios ou é autóctone que vive nas savanas do sudeste de Rupununi, região que também foi, em 1969, alvo de uma tentativa de separação da Guiana e envolveu a Venezuela. Em Essequibo há concentrações significativas de ouro, cobre, minério de ferro e níquel, além de diamante e manganês encontrados em quantidades suficientes para a produção comercial. O governo da Guyana, com a assistência da Guyana Oil Company (http://www.guyoil.com/), 
passou a explorar petróleo no interior da região. (DONAVAN, 2003).

Para tentar resolver esta disputa bastante persistente, os ministros das relações exteriores dos dois países aceitaram, em abril de 1990, o método de bons ofícios ${ }^{3}$, designando às Nações Unidas a arbitragem. Desde então, representantes dos dois governos reúnem-se frequentemente sob a mediação da ONU. Uma visita histórica à Venezuela em 1998 do presidente da Rep. da Guiana à época Janet Jagan, implicou em um acordo com o presidente venezuelano de então, Rafael Caldera, para continuidade do diálogo bilateral e assim resolver pacificamente a disputa territorial. (CAIRO CAROU; LOIS, 2014).

Mas a nova Constituição venezuelana, elaborada após a vitória de Hugo Chávez nas eleições de 1998, em que pese o acordo de continuidade nos diálogos anteriormente exposto, não deixou progredir a diplomacia com a Rep. da Guiana, uma vez que o documento continha várias passagens de caráter reivindicatório (VENEZUELA, 2010), mesmo que o presidente Chávez isentasse o país vizinho da responsabilidade do litígio. A reativação dos pressupostos do litígio por meio de sua nova constituição foi também uma reação ao que considerou um resultado humilhante da arbitragem das Nações unidas. Geopoliticamente tratava-se de uma maneira de se impor entre os líderes da ordem mundial atual.

No ano seguinte à Constituição venezuelana a Rep. da Guiana concedeu cerca de 100000 hectares para Beal Aerospace 4 instalar uma base

||||||||||||||||||||||||||||||||||||

3 A forma menos intrusiva de participação de terceiros envolve tentativas de facilitar a comunicação entre as partes envolvidas, mais comumente, oferecendo locais neutros para negociações (Good Offices). O Good Offices (Bons ofícios) é particularmente útil em situações em que os países em litígio não têm relações diplomáticas bem estabelecidas para assuntos gerais ou específicos que lhes digam respeito, como para a zona de fronteira comum, caso dos países aqui avaliados. Terceiros também podem desempenhar um papel mais ativo na resolução de litígios mediante a emissão de decisões vinculativas. A arbitragem é um tipo de ação de terceiros, que permite que o ator de fora possa tomar uma decisão que será considerada obrigatória para as partes em disputa. (HENSEL; TURES, 1997).

4 A empresa tem sede em Dallas, formada em 1997 pelo industrial Andrew Beal, para desenvolver, na iniciativa privada, foguetes para de lançamento de satélites na região de Essequibo. Vendo isto o governo venezuelano se opôs e, como retaliação, anunciou sua intenção de explorar petróleo na região disputada. (DONOVAN, 2003).

Nos anos 2000, o problema da delimitação entre a Venezuela e a Rep. da Guiana foi a origem de alguns incidentes diplomáticos. Em Junho de 2000, a Força de Defesa da Guiana apreendeu dez navios de pesca venezuelanos na sua zona econômica exclusiva (ZEE). Outros foram presos em 2002, sem que isto provocasse grandes tensões entre os dois países. (HOYLE, 2001; GRIFFITH, 2003). Em vez disso, para surpresa geral, o presidente venezuelano fez uma visita de Estado à Guiana em 2004, o que, mesmo não tendo resolvido o litígio, contribuiu para aumentar momentaneamente a confiança mútua. A calmaria, no entanto, durou pouco. Em 2007 as forças armadas venezuelanas realizaram uma incursão na área disputada, o que reavivou o litígio. As negociações pacíficas foram retomadas em 2011, na esteira de uma denúncia feita pela Guiana à ONU para estender sua plataforma continental para 150 milhas, o que implicava o território reivindicado pela Venezuela. (CAIRO CAROU; LOIS, 2014). A disputa territorial impede também a delimitação da fronteira marítima e assim paralisa qualquer iniciativa de exploração de petróleo na região. (HOYLE, 2001). O problema da delimitação das fronteiras marítimas, portanto, está profundamente enraizado com o problema das fronteiras terrestres.

Desde a morte de Hugo Chávez, em 2013, e através do método de bons oficios assumido pelas Nações Unidas, a diplomacia regional entre ambos avançou, mas por causa da importância da disputa territorial, é difícil prever cenários objetivos em médio e longo prazo. Davis (2002) considerou três cenários geopolíticos possíveis. O primeiro é que haverá um impasse em médio prazo, sem resolução alguma para o problema, com estabilização e

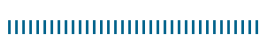

lançamento de satélites comerciais. Ele finalizou os negócios em outubro de 2000 por questões concorrenciais, mas não antes de ter testado o motor BA-810 - o segundo maior motor de foguete líquido-propulsor já construído nos Estados Unidos (<http://www. daviddarling.info/encyclopedia/B/Beal_Aerospace.html $>$. Acesso em 15 dez. 2014). 
sem incursões militares na área discutida. $\mathrm{O}$ segundo cenário é que, aproveitando a fragilidade econômica da Rep. da Guiana (este é o segundo estado mais pobre da América do Sul, depois da Bolívia), a Venezuela poderia encontrar um pretexto para tirar à força o controle do território em disputa. A terceira possibilidade é que os dois países trabalharão juntos para encontrar uma solução duradoura e mutuamente satisfatória para a disputa de fronteira.

Adicionaríamos uma quarta opção ao proposto por Davis. Ambos os países respeitarão o método de bons ofícios e definitivamente resolverão o litígio. $\mathrm{O}$ problema é que a área perdida pela Rep. da Guiana, caso seja dado ganho de causa à Venezuela, seria mais da metade do país, o que agravaria - e muito - sua capacidade de desenvolvimento regional.

No curto prazo, provavelmente haverá uma continuação do status quo. Esta situação, no entanto, torna-se insustentável em longo prazo, especialmente no que tange à demanda crescente por petróleo nos mercados internacionais, que é em parte comprometida na região por conta das disputas marítimo-territoriais. Além disso, a troca de dirigentes de ambos os países, tal como salienta Valero (2011) para o caso venezuelano, sempre provocará tensão à medida que não se saberá ao certo qual será efetivamente a política diplomática para a área contestada. O mesmo autor destaca que, por uma parte, recorrentemente ambos os países declaram a firme posição em buscar soluções pacíficas para a controvérsia limítrofe. Paralelamente, por outra, e em via contraria a este ambiente de solução, insistem em reafirmar direitos territoriais nas altas esferas governamentais de cada âmbito nacional. A falta de resolução do litígio, com efeito, reflete-se na porosidade transfronteiriça entre ambos. Atualmente o cruzamento da fronteira é tenso e conta com proteção militar de ambos os lados ${ }^{5}$.

Sem conexões físicas ligando os dois estados, há uma quebra de continuidade da "transguianense"

\section{|||||||||||||||||||||||||||||||||||}

5 Não foi possível realizar trabalho de campo nesta zona de fronteira. Por isso, a base de reflexão é documental e isso reflete na falta de fotos sobre esta área de estudo.
(Mapa 3), uma via costeira formada por várias rodovias dos países das guianas. Esta fronteira terrestre fechada simboliza a magnitude da tensão na região das Guianas, embora os dois estados façam parte de órgãos comuns como a OTCA, AEC, e agora a UNASUL e a CELAC 6 .

A disputa Guiana-Venezuela representa o terceiro maior litígio no subcontinente, depois daqueles que envolvem Chile-Bolívia e PeruEquador, mas é a primeira em superfície disputada em relação à área total do mundo. (FOUCHER, 1988).

\section{O caso do triângulo do New River}

A expressão Triângulo do New River (TNR) denomina uma área reclamada pelo Suriname, com extensão de aproximadamente $6.000 \mathrm{~km}^{2}$ (Tabela 1), na sua tríplice fronteira entre Brasil ao sul, Suriname ao leste e Guiana ao oeste (Mapa 2). A disputa é por qual rio, New River ou Kutari, seria o afluente principal do Corantyne ${ }^{7}$, rio-limite na fronteira guiano-surinamesa (Mapas 2 e 3 ).

A fronteira terrestre entre as Guianas britânica e holandesa foi definida em 1799 pelas suas autoridades coloniais ao longo da margem oeste do rio Corentyne. A fixação da fronteira em uma das margens deste rio e não no seu meio permitiu que os holandeses controlassem todo o tráfego no Corentyne, aspecto importante quando se considera que, nesta região, os rios são as principais vias de comunicação. (LÉZY, 2000; GAO, 2009). Ao sul do Corentyne, o rio Kutari constituiu, até 1921, a fronteira histórica entre as colônias britânicas e holandesas. Mas, a

IIIIIIIIIIIIIIIIIIIIIIIIIIIIIIIIIII

6 OTCA - Organização do Tratado de Cooperação Amazônica, dos quais os oito estados envolvidos pelo ecossistema amazônico são membros desde 1978; AEC - Associação dos Estados do Caribe, uma estrutura consultiva da qual a França também e seus departamentos e comunidades da América do Sul pertencem (Martinica, Guadalupe, Saint-Barthélemy, Saint-Martin e Guiana Francesa); UNASUL - União das Nações Sul-Americanas, uma estrutura consultiva dos estados sul-americanos fundada em 2004; CELAC: Comunidade dos Estados da América Latina e do Caribe, um fórum político constituído em 2010 pelos Estados do mundo americano, com exceção dos Estados Unidos e do Canadá.

7 Chamado também de "Corantijn", em holandês, ou "Corentyne", "Corentin", "Corentyn", "Korentyn" e "Corantine". 
Mapa 3. Interações nas fronteiras do Suriname.

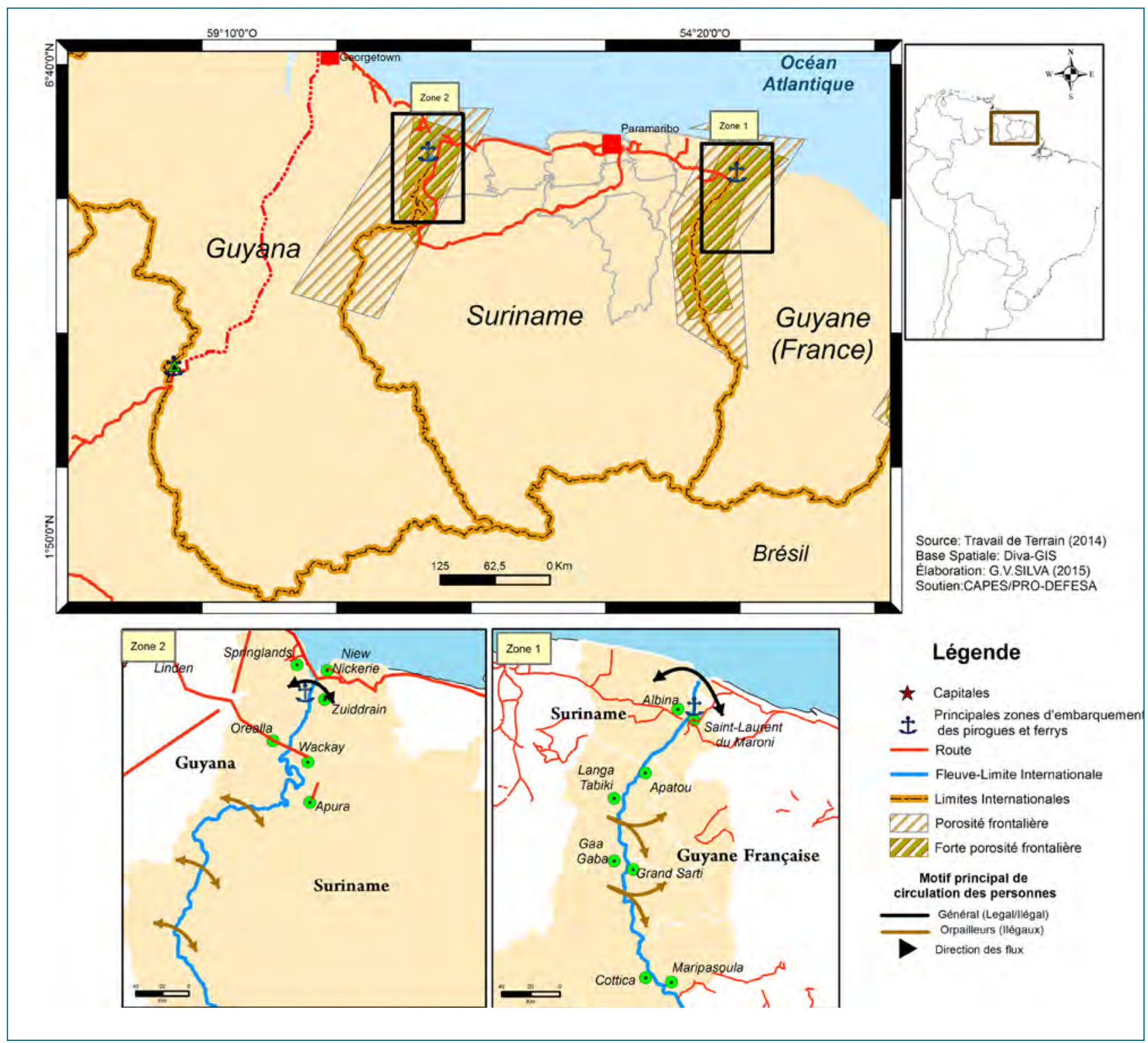

partir de então, os holandeses concluíram que o New River seria o principal afluente do Corentyne e reposicionaram para lá a fronteira internacional, incorporando mais de $6000 \mathrm{~km}^{2}$ ao seu território. Em 1930, um acordo restabeleceu o rio Kutari, mas a eclosão da Segunda Guerra Mundial, em 1939, impediu a sua formalização. As negociações só seriam retomadas em 1962 quando os holandeses exigiram novamente os limites no New River. (JOSEPH, s/d; DONOVAN, 2003, 2005).

Após a independência da Guiana o princípio da linha equidistante do curso do rio Corentyne foi utilizado para determinar a posição daquela fronteira internacional. No entanto, as tentativas holandesas de controlar o território se intensificaram ainda naquela década, notadamente por meio das Forças Armadas. (RAMRAJ, 2002). Até o início dos anos 1970 as tropas da Guiana conseguiram ocupar com sucesso o triângulo do New River. (GAO, 2009). Mas, quando o Suriname tornou-se independente em 1975, um componente da sua recém criada diplomacia foi adquirir a área disputada. (RAMRAJ, 2002).

A probabilidade de um conflito armado é baixa, principalmente por causa de iniciativas de cooperação regional que se iniciaram a partir da década de 1980. Em 1986, por exemplo, foi criado o Conselho de Cooperação Guiana-Suriname 
para impulsionar o desenvolvimento econômico regional. Além disso, Guiana e Suriname são membros do Mercado Comum do Caribe, CARICOM, e, como a Venezuela, participam em outras organizações políticas como a AEC, a OTCA e a UNASUL.

Mesmo com este cenário pouco propenso à militarização, as tensões foram revividas quando, na década de 1990, o Suriname começou a publicar mapas oficiais que mostravam a região reivindicada como parte do seu território (ver SURINAME, 2010; 2013). O Governo da Guiana considerou tal atitude uma provocação e até hoje, o que representa uma ameaça significativa à integridade territorial da Guiana, não foi resolvido. (DONOVAN, 2005).

O território disputado é povoado por cerca de 5000 pessoas. São índios e noir-Maroons (descendentes de escravos que fugiram dos governantes coloniais de holandeses e britânicos), que realizam em sua maioria a prospecção de ouro e diamantes, movendo-se de forma intermitente em toda a região. De fato, há uma abundância de recursos minerais na região, sobretudo de bauxita e metais preciosos, como reservas de ouro e petróleo (RAMRAJ, 2002), e há probabilidade da presença de ouro e diamantes em todo o seu interior. O Governo da Guiana, pensando em reforçar sua força territorial e ao mesmo tempo arrecadar dividendos, concedeu à Malásia Corporation no início de 2000 o direito de exploração de mais de 500.000 hectares na área litigiosa. Por outro lado, este país, mas o Suriname também, incentiva aventuras de exploração de garimpeiros na área disputada (DONOVAN, 2003) para demarcar possessões para habitantes de seus respectivos países.

Em 1997, o Governo da Guiana garantiu financiamento do Banco Mundial com uma política ambiental de proteção e redução dos níveis de dióxido de carbono na atmosfera em uma região que incluía o triângulo do New River, reafirmando assim a sua soberania sobre este território perante a comunidade internacional. Ressalte-se que os rios Corentyne, New River e Kutari possuem capacidade hidrelétrica quase ilimitada. Um projeto de usina hidrelétrica realizado para o
Governo da Guiana foi abortado em razão de obstáculos geomorfológicos e topográficos, mas também por causa da distância da área em disputa e das principais cidades do Suriname que são todas costeiras. (DONOVAN, 2003).

Atualmente, o Governo do Suriname não mostra nenhum desejo considerável em ocupar e operar o triângulo do New River, embora, como já vimos, o país mostre esta área como parte de sua soberania. Esta posição também é apoiada pelo fato de que algumas organizações internacionais não menos importantes, como a ONU, publicaram mapas que mostram a área também como pertencente ao Suriname. Além disso, o Suriname ingressou em 2012 na Aliança Bolivariana para a América Latina (ALBA), uma associação política dos Estados criada em 2005 por iniciativa do presidente da Venezuela, Hugo Chávez, a fim de neutralizar a influência dos EUA na região.

Por seu turno, a Rep. da Guiana encontra-se imprensada entre dois estados no sentido leste e oeste que reivindicam parte de seu território, mas pode contar com um apoio mais ou menos tácito do Brasil, país fronteiriço ao sul, ansioso para evitar uma forte influência venezuelana em uma região que considera sensível e com interface com o mundo caribenho. (GRANGER, 2016).

\section{O caso dos afluentes do rio Lawa}

O Suriname também está envolvido em outra disputa territorial, esta agora com a França. A ex-colônia holandesa reclama, desde meados do século XVIII, a soberania sobre uma área de 5000 $\mathrm{km}^{2}$, localizada entre os rios Litani (ou Itany) e Marouini, ambos afluentes do rio Lawa, principal afluente do rio Maroni, rio que forma, como o corantyne na sua outra ponta, a fronteira com a Guiana Francesa (Mapa 2). O curso do rio Lawa e seus afluentes foram ignorados por muito tempo, mas ao longo das últimas três décadas do século passado, técnicas avançadas de mapeamento trouxeram mais conhecimento sobre a região.

No século XVIII, a França e os Países Baixos procuravam, de acordo com as concepções da época, um elemento natural para fixar sua fronteira. $\mathrm{O}$ 
rio Maroni foi escolhido no Tratado de Extradição Recíproca de desertores, concluído em 1770 entre os respectivos governos (GRIFFITH, 2003). No século seguinte, o rio se tornou mais conhecido através da exploração sistemática realizada no interior de ambos os assentamentos, momento no qual se descobriu ouro na região. Com isso, o problema de determinar o principal afluente do rio Maroni à montante retornou novamente. $\mathrm{O}$ czar russo Alexander III foi escolhido como o árbitro para escolher entre os rios Lawa e Tapanahoni qual seria a fronteira naquele perímetro. Sua sentença, depois de 12 dias (de 13 a 25 de maio de 1891) definu o rio Lawa como o limite, atribuindo assim à Holanda $60.000 \mathrm{~km}^{2}$ de terra rica em minerais, especialmente bauxita. À época, esta área foi considerada como um dos maiores depósitos do mundo. (ANUÁRIO FRANCÊS DE DIREITO INTERNACIONAL, 1956).

Em outubro de 1938 novas propostas foram apresentadas ao governo holandês, que as aceitou após longas negociações. A fronteira internacional foi então colocada sobre o crique ${ }^{8}$ Coulé-Coulé, entre os rios Litani e Lawa, à montante da ilha Soteilman e ao sul da parte inferior da calha do rio Maroni. Com base nas propostas francesas, o Instituto Geográfico Nacional francês mostrou, em 1938, um mapa demarcando o que foi acordado, mas o governo holandês nunca o reconheceu, nem mesmo com a pesquisa realizada pelo Instituto de Investigação Científica e Técnica do Ultramar (Institut de Recherche Scientifique et Technique de l'Outre-Mer - IRST-OM) que, em 1957, colocou o limite no curso superior dos rios Marouini e Litani, determinando o Litani como principal afluente do Lawa. (ANUÁRIO FRANCÊS DE DIREITO INTERNACIONAL, 1956).

Com a independência do Suriname, em 1975, adotou-se a linha holandesa. Mas em 1997 o governo do Suriname aceitou a linha francesa em troca de colaboração financeira para o seu desenvolvimento, o que foi efetivado com os investimentos do Fundo de Cooperação Regional (FCR) da França e do Programa Operacional

||IIIIIIIIIIIIIIIIIIIIIIIIIIIIIIIII

8 A palavra "crique" designa uma espécie de canal fluvial.
Amazônia -POAmazônia, um programa europeu voltado para o desenvolvimento econômicos dos territórios ultramarinos da Europa. (IEDON, 2006; FRANÇA, 2007; SILVA, 2013a). Recentes acordos sobre os limites internacionais entre Suriname e França aguardam ratificação para a resolução definitiva desta reivindicação territorial, mas é possível afirmar que tal litígio já está praticamente resolvido com o acordo financeiro estabelecido por ambos os países.

Toda a extensão da fronteira entre Suriname e França, com efeito, é marcada hoje por uma clara diferença de padrões urbanos das cidades fronteiriças. As maiores cidades e onde há intensa porosidade, Albina do lado surinamês e Saint Laurent du Maroni do lado francês, enquadram-se nesse contexto (Fotos 1 e 2), na medida em que a cidade francesa é mais organizada, tem melhores serviços e padrões de vida do que a holandesa.

Ambos os países exigem visto de entrada, mas o cruzamento transfronteiriço nas cidades mencionadas não apresentam problemas aparentes quanto à circulação de pessoas e mercadorias entre elas. Há uma clara dependência econômica do lado surinamês em relação ao francês. Muitos produtos comercializados do lado francês, contudo, são oriundos, em termos não-oficiais, do Suriname, vindos através de pequenas embarcações que circulam entre ambos os lados da fronteira (Foto 1, Mapa 3).

Os franceses, tal como na fronteira com o Brasil, combatem a garimpagem ilegal que ocorre em seu território (Mapa 3), muitas vezes realizada por garimpeiros brasileiros que circulam diariamente a fronteira entre o Suriname e a Guiana Francesa. Brasileiros no Suriname, que estão como turistas, não precisam de visto. Após os 90 dias de entrada como turista, os garimpeiros brasileiros cruzam a fronteira guiano-surinamesa e lá ficam apenas um dia para poder retornar ao Suriname novamente por mais 90 dias. Isso se faz por muitos garimpeiros e muitas vezes ao ano. Há alguns anos o cruzamento na fronteira em questão poderia ser feito no mesmo dia, mas como a circulação de pessoas aumentou significativamente, a Guiana passou a exigir a permanência de pelo menos um dia em seu território. 
Foto 1. Mosaico de fotos de Albina (Suriname) e Saint Laurent (França/Guiana Francesa).

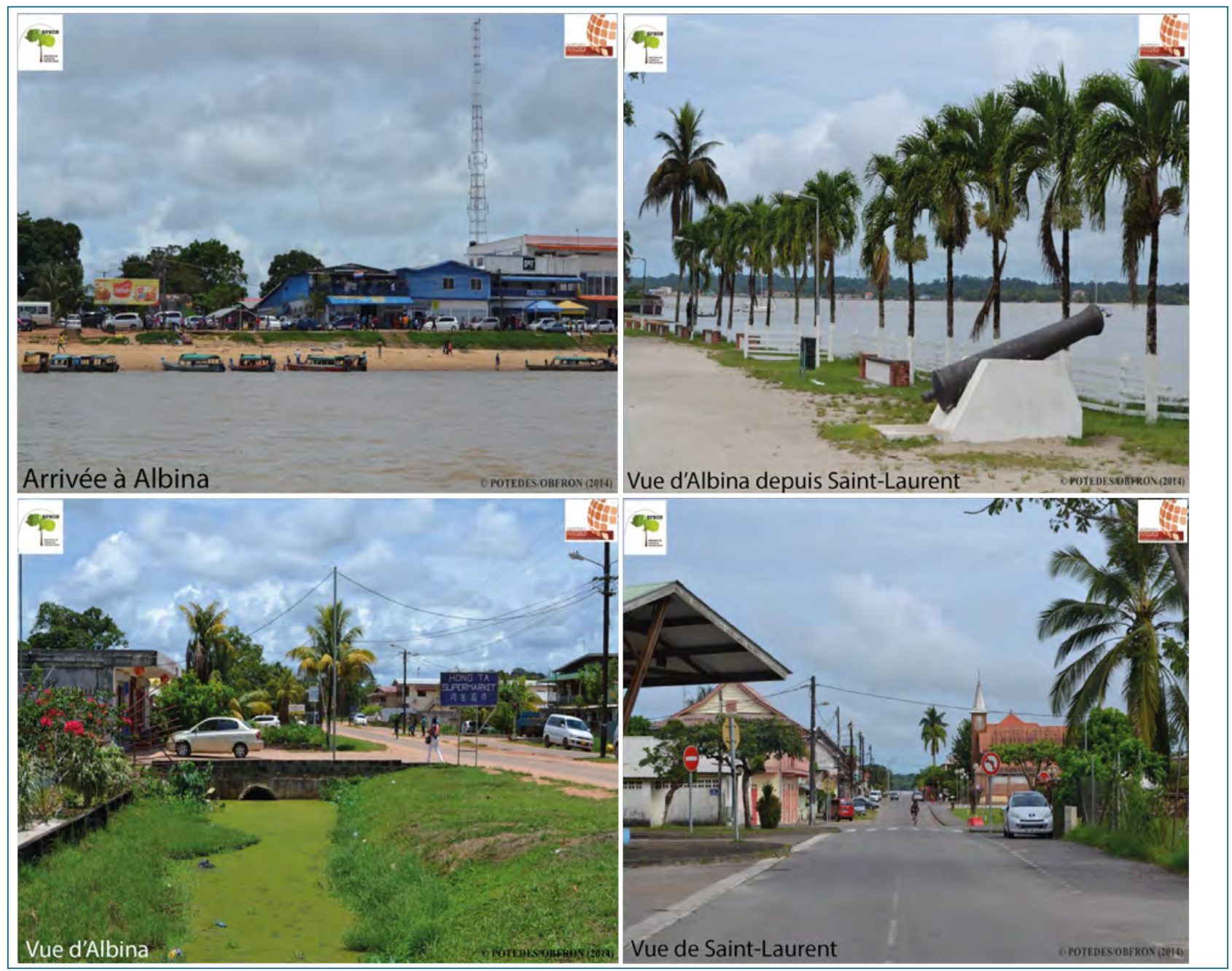

Fonte: Trabalho de Campo, 2014.

Mesmo com a circulação ilegal de mercadorias e pessoas na fronteira franco-surinamesa, há uma proposta de se construir uma ponte binacional sobre o rio Maroni ligando fisicamente ambos os países (ver ABDENUR, 2013). Esta proposta, em nossa compreensão, está longe de ser efetivada, pois a França não tem interesses estratégicos com a ligação física transfronteiriça, embora isso possa significar uma maneira da Guiana Francesa sair do isolamento físico regional.

Como visto até aqui, a contestação do limite territorial no platô das Guianas é uma marca relevante entre os países avaliados. Além destes litígios, ainda há disputas pelos domínios marítimos. A bacia da Guiana é, nesse caso, colocada em relevo e após as descobertas de reservas de petróleo na região (Mapa 4), tensões e arranjos geopolíticos movimentaram a diplomacia entre a Rep. da Guiana e o Suriname em diferentes contextos históricos, sendo este o foco da seção a seguir

\section{As reivindicações marítimas}

As reivindicações marítimas formam atualmente o mais numeroso caso de disputas de fronteira entre os Estados. De fato, das mais de 400 disputas marítimas listadas, apenas $50 \%$ foram resolvidas. (BRUNET-JAILLY, 2015, p.xvii). Ilustrando essa situação, estados das Guianas estão implicados em contestações de delimitações por seus territórios marítimos, tal como mostra o Mapa 2. 
Mapa 4. Reservas de Petróleo e Concessões na Bacia Guiano-Surinamesa.

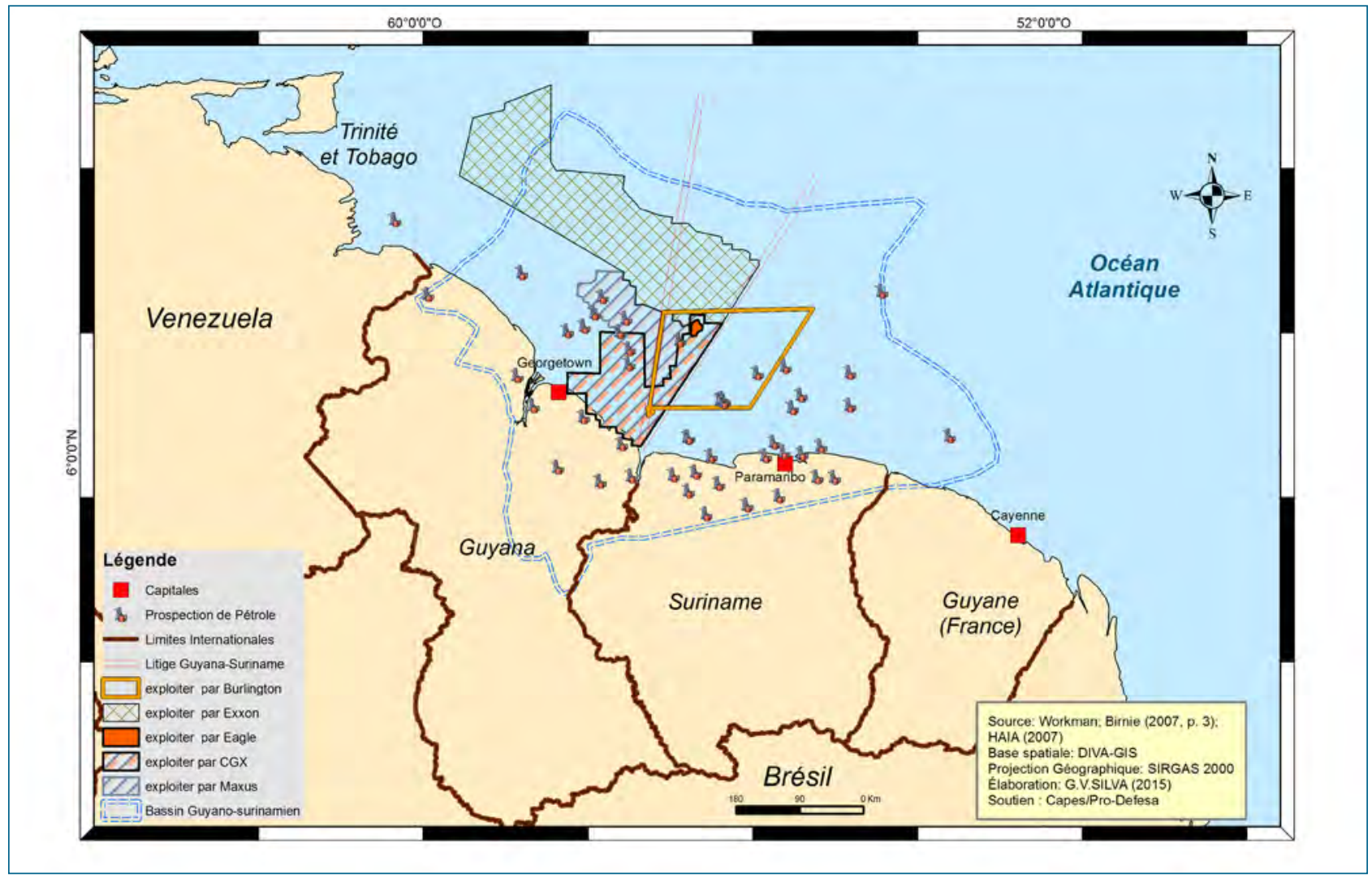

Uma reivindicação marítima envolvendo a Rep. da Guiana e o Suriname não possui resolução até hoje e igualmente envolve o rio Corentyne em relação à linha marítima que se estende à jusante deste rio. Relatos do final de 1920 apontam que o petróleo tinha sido descoberto a leste do Corentyne, obrigando britânicos e holandeses a abordarem a questão da localização precisa do limite na porção superior daquele rio. Os holandeses avançaram na margem oeste do Corentyne, estabelecendo-lhe como a fronteira internacional o que denotava ser o Corentyne um rio holandês. (HOYLE, 2001).

As reivindicações marítimas nesta área envolvem todo o espaço marítimo entre a Guiana e Suriname. A área marítima disputada entre os dois países é na bacia da Guiana, ao longo da foz do Corentyne. Esta é uma área ainda sub-explorada na plataforma continental da América do Sul, que se estende da Venezuela até o Suriname (Mapa 4). A Bacia da Guiana é geograficamente próxima de importantes produtores de petróleo no Caribe. Em toda esta área, grandes consórcios petrolíferos comerciais, como Exxon, Agip, e Burlington, já realizaram perfurações com sucesso. (DONOVAN, 2003).

O Suriname reivindica uma extensão da sua plataforma continental para o meridiano $10^{\circ}$ leste, enquanto que a Rep. da Guiana reivindica $33^{\circ}$ Leste, como mostrado no mapa de cima. A área resulta em uma disputa sobre uma zona marítima de $31.600^{2}$ (Tabela 2). Foi entre estes dois países por tal disputa que surgiram os incidentes fronteiriços mais graves na região: em 1978, por falta de acordo em relação à fronteira marítima, embarcações surinameses foram detidas por canhoneiras da Rep. da Guiana, enquanto que no ano de 2000 a situação ocorreu de maneira inversa. (HOYLE, 2001). Em 1936, a Holanda e o Reino Unido tinham formado uma comissão mista para demarcar a fronteira terrestre entre suas respectivas colônias, mas a Segunda Guerra Mundial impediu a ratificação do Tratado proposto pelos britânicos em 1939. 
Mapa 5. Última Definição de Limites Marítimos entre Guyana e Suriname.

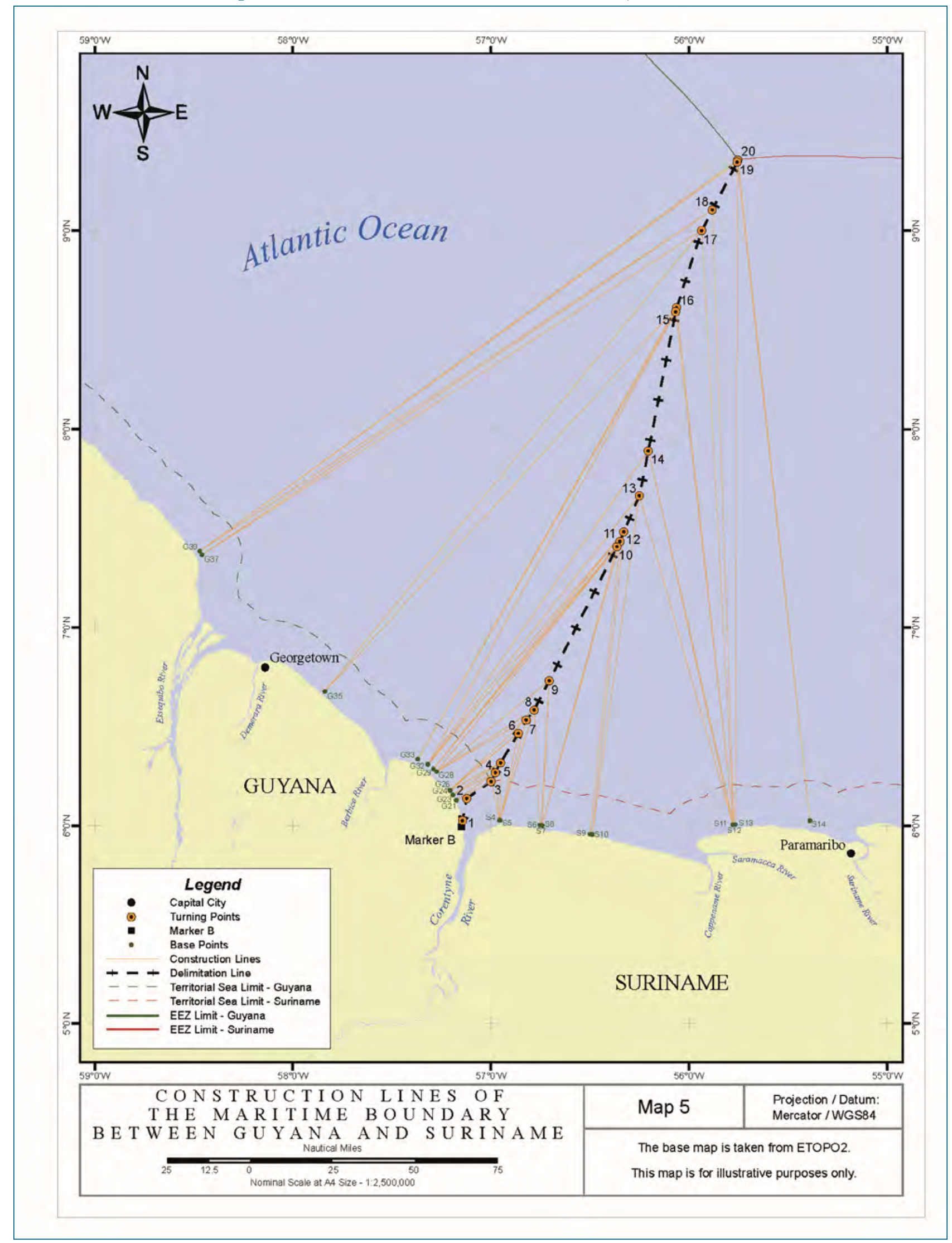


Na década de 1950, quando o governo britânico lançou uma aventura por petróleo, holandeses e britânicos concordaram com a delimitação pelo princípio da eqüidistância definido pela ONU em Convenção de 1958. As novas propostas britânicas apresentadas em 1961 estabeleceram: 1) a soberania holandesa sobre o Corentyne; 2) uma linha de $10^{\circ}$ leste para a delimitação das zonas marítimas ${ }^{9}$; e 3) a soberania britânica sobre o Triângulo do New River - três aspectos propostos anteriormente em 1936. (HOYLE, 2001). O governo holandês emitiu uma contraproposta no ano seguinte decidindo aceitar a fronteira à montante do Corentyne. Para os holandeses, o limite deve seguir uma linha que acompanhe um azimute real de $10^{\circ}$ norte depois do marco 61 fixado em 1936 (ponto final do talvegue), o que causou um retorno para o ponto de partida nas negociações. Este status quo perdurou após a independência da Rep. da Guiana.

Um novo dado surgiu em 1982 com a assinatura da Convenção das Nações Unidas sobre o Direito do Mar, conhecida como Convenção de Montego Bay, um tratado multilateral que define novas regras de direito internacional do mar, incluindo o estabelecimento de ZEE's e o conceito jurídico da plataforma continental, a criação do Tribunal Internacional do Direito do Mar (TIDM), a jurisdição sobre as controvérsias relativas à interpretação e aplicação do Tratado (ONU, 1982), entre outros. O Papel do TIDM foi importante no caso de reivindicações territoriais e marítimas relativas as Guianas.

A disputa tornou-se realmente mais e mais sensível com a descoberta das reservas de petróleo na área disputada. Em Junho de 2000, um estudo realizado pelo US Geological estimou que os recursos potenciais ao longo do estuário do Corentyne seriam de 15,2 bilhões de barris de petróleo, o que tornaria esta região a segunda zona de petróleo do mundo em potencial para

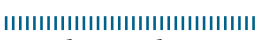

9 Todo Estado tem o direito de fixar a largura do seu mar territorial até um limite que não ultrapasse 12 milhas marítimas ( $1 \mathrm{~m} . \mathrm{m} .=$ 1.852 metros), medidas a partir de linhas de base determinadas em conformidade com a presente Convenção (ONU, 1982, Art. 3). exploração. Se esse potencial for comprovado, ela tornar-se-ia ainda mais produtiva. Uma pesquisa feita por CGX, empresa sediada em Toronto (Canadá) e que atua sistematicamente na bacia da Guiana, considerou que o fator de risco (probabilidade de ter um petróleo comercial viável) ao longo da foz do Corentyne estava em torno de 35\% (DONOVAN, 2003), ou seja, um potencial interessante para exploração. As autoridades da Guiana propuseram então compartilhar as receitas geradas por concessões na área disputada entre os dois estados. No entanto, o Suriname se manteve firme em sua exigência de que a Guiana não deveria conceder nenhuma licença de exploração da área. (TANAKA, 2007).

Em 24 de fevereiro de 2004, devido ao fraco progresso nas negociações diplomáticas (falhou a mediação do CARICOM), a Rep. da Guiana solicitou a arbitragem da ONU sobre a linha de delimitação tomando por base os fundamentos do Anexo VII da Convenção das Nações Unidas sobre o Direito do Mar. (ONU, 2014). Este país também reclamou para si compensações por ameaças e uso da força pelo Suriname e a não atribuição da concessão à empresa canadense CGX, em 2000. (TANAKA, 2007).

Depois a audiência, a sentença do Tribunal, em 17 de Setembro de 2007, se dividiu em três partes: delimitação das águas territoriais e 3 milhas náuticas; delimitação das águas territoriais entre 3 e 12 milhas náuticas; e a delimitação da plataforma continental e da ZEE (o mapa 5 mostra o status mais recente), dando razão à Guiana, mas rejeitando o seu pedido de reparação por insuficiência de documentos comprovando os danos. Esta decisão confirma a validade jurídica atribuída ao caso, enriquecendo a jurisprudência sobre esta questão. (TANAKA, 2007). Mas os dois países ainda têm de confirmar e ratificar a sentença da ONU, mas parece que a sentença não foi bem aceita pelo Suriname.

Este tipo de resolução de disputa territorial ilustra o quarto cenário discutido acima, em que dois estados respeitam a decisão de um organismo internacional para demarcar a sua fronteira (bons ofícios). Fato inconteste é que a Rep. da Guiana 
estaria em uma situação difícil se perdesse a questão.

O difícil tráfego transfronteiriço entre a Rep. da Guiana e o Suriname é um resultado direto de tensões diplomáticas entre os dois países como fruto direto das reivindicações marítimoterrestres. É facilmente possível atravessar a fronteira internacional com o auxílio de um ferryboat que liga as cidades de Nieuw Nickerie (Suriname) e Skeldon (Foto 2). A cidade de Springland, ao lado Skeldon, transformou-se em dormitório para os garimpeiros brasileiros e ponto de apoio aos veículos que vão para Georgetown, capital da Rep. da Guiana. A situação é muito diferente em Nickerie, a terceira maior cidade do Suriname, uma grande produtora de arroz e um dos principais produtos de consumo e exportação do setor primário do Suriname.

Se observa grande mobilidade dos garimpeiros em ambos os lados da fronteira (Mapa 3), mas o tráfego transfronteiriço é altamente ameaçado pelas tensões diplomáticas e isso retarda a integração regional proposta pela UNASUL, da qual pertencem tanto Guiana, quanto Suriname

Foto 2. Mosaico de fotos na fronteira Guiano-Surinamesa.

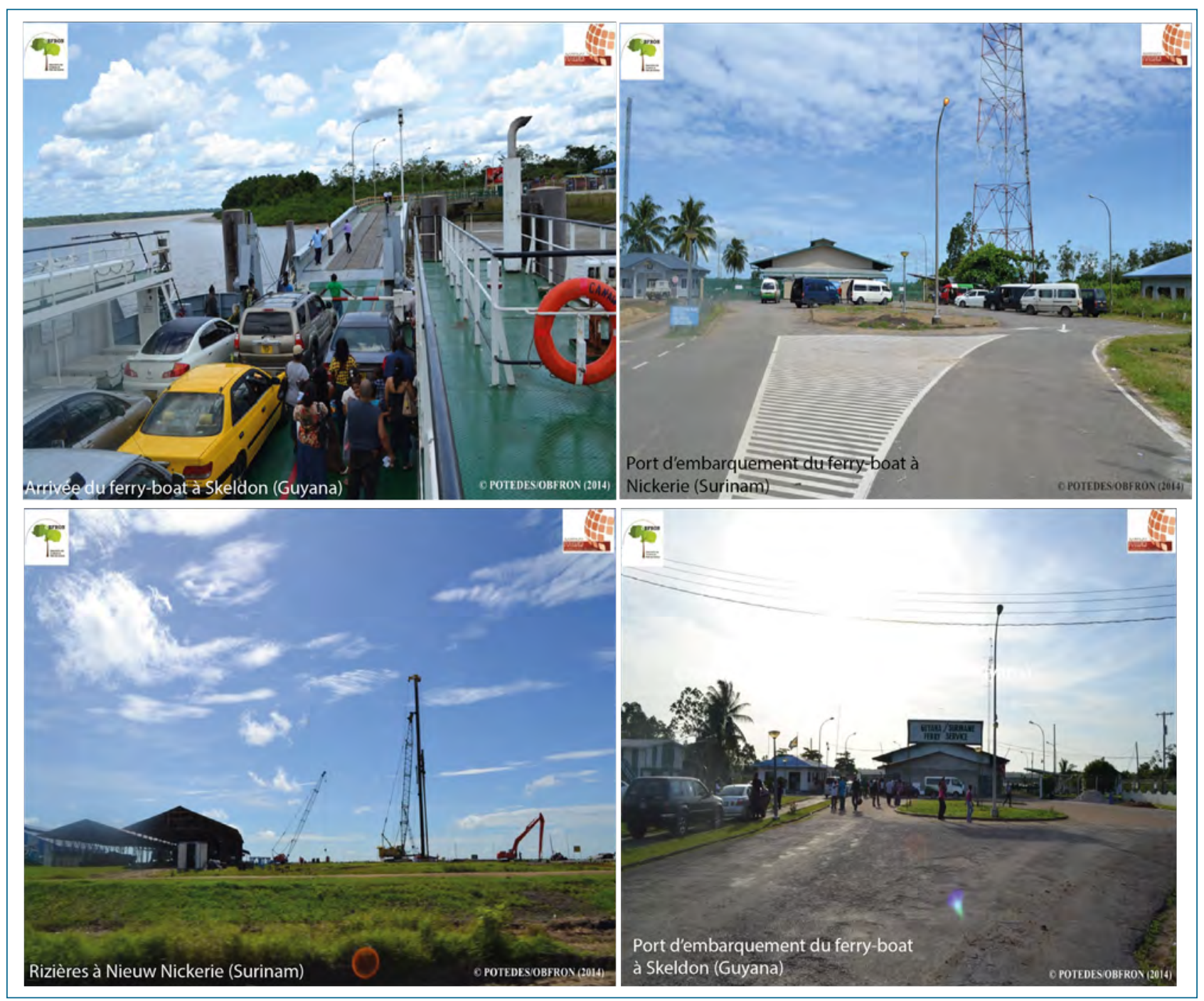

Fonte: Trabalho de campo, 2014. 
e Venezuela. O projeto IIRSA-COSIPLAN ${ }^{10}$ prevê obras de infraestrutura para facilitar a circulação de mercadorias na rodovia transguianense, destinada a se tornar em seguida uma estrada Panamericana-Atlântica ${ }^{11}$.

\section{Conclusão}

Limites e fronteiras internacionais constituem pontos importantes de reflexão em geopolítica e geo-história, e nossas análises aqui são exemplos significativos. Todos os estados da região das Guianas, exceto Brasil, estão mergulhados em reivindicações marítimas ou territoriais e a essência do que está essencialmente em jogo tem a ver com ganhos ou perdas econômicas em relação a anexação ou amputação de territórios.

Duas grandes frentes de disputas dizem respeito aos países da região das Guianas: o território continental (Essequibo, Triângulo do New River e Lawa) e o território marítimo (principalmente a plataforma continental como no caso do litígio Guiana-Suriname). Em ambos os casos, a dimensão econômica é fundamental, especialmente a partir da segunda metade do século XX quando o petróleo ganhou extrema importância na geopolítica internacional e se tornou um objeto de desejo para as grandes empresas que trabalham no Planalto das Guianas.

Dois outros minerais também foram importantes na geopolítica e na geo-história regional: o ouro e a bauxita. Assim, a perda eventual de territórios acrescentaria recursos existentes e os potenciais, especialmente quando consideramos as reservas de petróleo ainda inexploradas; Também desistir de territórios nas Guianas é ainda mais impensável. Com exceção da Guiana Francesa, nas Guianas estão alguns dos países mais pobres da América do Sul em termos de desenvolvimento humano e econômico. Lá também se conheceu fortes contrastes em termos militares e econômicos entre os estados, como

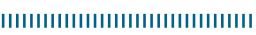
10 Ver <http://www.iirsa.org>.

11 Por oposição à Panamericana-Pacífico, ao longo dos Andes na costa ocidental da América do Sul. no caso da Venezuela em comparação a Rep. da Guiana.

Em todos os casos técnicas de mapeamento e, mais recentemente, os de telecomunicações trouxeram argumentos mais claros e objetivos para resolver as históricas disputas marítimoterritoriais. A alta precisão de ferramentas modernas traz uma contribuição nova e essencial às resoluções adotadas pelas designadas organizações internacionais, como foi o caso da delegação dada para as Nações Unidas no caso da disputa marítima entre a Guiana e Suriname.

No caso da disputa entre a França e Suriname está praticamente resolvida. O Suriname, relativamente isolados diplomaticamente, procura apoio financeiro da França e parece ter abandonado a sua reivindicação contra este país em troca de recursos financeiros. Atualmente apenas permanecem alguns ajustes administrativos a serem feitos para a assinatura de um tratado. No entanto, isso está longe de ser o caso das disputas do Suriname com a Rep. da Guiana. Se este perder as disputas das quais faz parte, perderá a maior parte de seu território em todas as direções (exceto no sul, onde está sua fronteira com o Brasil).

Dois temas não abordados neste artigo podem dar origem a futuras investigações. A primeira é a geopolítica do petróleo, indissoluvelmente ligada à resolução de disputas marítimo-territoriais no Planalto das Guianas. A outra é a integração política, econômica e regional das Guianas, incluindo a construção de infra-estrutura de comunicação prevista em especial nas propostas da IIRSA-COSIPLAN. Assim, a integração gradual adiciona novos problemas geopolíticos aos das fronteiras internacionais desses países.

\section{Referências}

ABDENUR, A. E. South-South Cooperation in Suriname: New Prospects for Infrastructure Integration?, Institute for the Integration of Latin America and the Caribbean, v.17, n. 36, 2013. p. 101-110.

AKEHURST, M. A Modern Introduction to International Law, Sixth edition, New York, Routledge, 1987.

ANUÁRIO FRANCÊS DE DIREITO INTERNACIONAL. A propos de la délimitation des frontières de la Guyane française, v.2, 1956. p. 255-259. 
BRAUDEL, F. Géohistoire : la société, l'espace, le temps, in Ayala, R, Braudel, F., Braudel, P, Les ambitions de l'histoire, Paris, Éditions de Fallois, 1997. p. 68-114.

BRUNET JAILLY, E. Border Disputes, A Global Encyclopedia, vol. 1, Territorial disputes, Santa Barbara (CL) / Denver (CL), ABC-CLIO, LLC, 2015.

CAIRO CAROU, H.; LOIS, M. Geografía política de las disputas de fronteras: cambios y continuidades en los discursos geopolíticos en América Latina (1990-2013), Cuadernos de Geografía, v. 23, n. ${ }^{\circ}$ 2, 2014. p. 45-67.

CIA (Central de Inteligência Americana. Latin America: Compendium of Bondaries and Territorial Disputes. A Research Paper. Inteligence Report, 1995.

DOMÍNGUEZ, J. L. et al. Boundary Disputes in Latin America, Peaceworks n. 50, First published September, 2003.

DONOVAN, T. W. Suriname-Guyana Maritime and Territorial Disputes: A Legal and Historical Analysis, Flórida, Jornal de lei transnacional e Política, Université de Floride. Vol. 13, 2003.

DONOVAN, T. W. Challenges to the Territorial Integrity of Guyana: A Legal Analysis, Geórgia, Jornal de Lei Internacional e Comparativa, vol. 32, 2004.

DUSSOUY, G. Conceptualiser et (re)problématiser la géopolitique sans faire de théorie. Les théories de la Géopolitique, L’Espace Politique, [En ligne], v 12, 20103, 2010, mis en ligne le 11 février 2011, consulté le 12 février 2017. Disponivel em: <http://espacepolitique. revues.org/1712>.

EGGER, J. Vista geral sobre a economia do Suriname nos séculos XIX e XX, Diplomacia, Estratégia e Política, Brasília, Projeto Raúl Prebisch, n. 10, 2009. p. 205-219.

FOUCHER, M. Fronts et frontières. Un tour du monde géopolitique, Paris, Fayard, 1988.

GABRIEL-OYHAMBURU, K. Le retour d'une géopolitique des ressources? Les théories de la géopolitique, L'Espace Politique, [En ligne], v.12, 2010-3, 2010, mis en ligne le 11 février 2011, consulté le 12 février 2017. Disponível em: 〈http://espacepolitique.revues.org/1796>.

GAO, J., Comments on Guyana v. Suriname, Chinese Journal of International Law, vol. 8, no. 1, 2009. p. 191-203.

GRANGER, S. Intégrations régionales et diversification des flux migratoires dans les mondes caribéen et amazonien: la Guyane entre ouverture et isolement, in : Collomb, G. et Mam Lam Fouck, S. (dir.), La Guyane entre Surinam et Brésil: mobilités, ethnicités, diversité culturelle, Matoury, Ibis Rouge, 2016. p. 25-47.

GRIFFITH, I. L. The Caribbean Security Scenario at the Dawn of the 21st Century: Continuity, Change, Challenge, NorthSouth Agenda Papers, Number Sixty Five: University of Miami, 2003.

GUICHONNET, P. ; RAFFESTIN, C. Géographie des Frontières, Paris, PUF, 1974.

GUYANA, The Guyana-Suriname Boundary: A Historical Review, Guyana News and Information, 2014.
HENSEL, P. R. Territorial Disputes and Interstate Conflict: Empirical Patterns and Theoretical Explanations. Communication, Scientific Knowledge of War: Identifying Patterns, Constructing Explanations. Vanderbilt University, 1997.

HENSEL, P. R.; TURES, J. International Law and the Settlement of Territorial Claims in South America, 18161992, Presented at the annual meeting of the American Political Science Association, Washington, D.C, 1997.

HOYLE, P. A. The Guyana-Suriname Maritime Boundary Dispute And Its Regional Context, IBRU Boundary and Security Bulletin, Summer, 2001.

HUTH, P. K. Standing Your Ground: Territorial Disputes and International Conflict. Ann Arbor: University of Michigan Press, 1996a.

HUTH, P. K. Enduring Rivalries and Territorial Disputes, 1950-1990, Conflict Management and Peace Science, v 15, 1 (Spring), 1996b, p. 7-42.

JACOB-ROUSSEAU, N. Géohistoire/géo-histoire : quelles méthodes pour quel récit ?, Géocarrefour, [En ligne], vol. 84/4, mis en ligne le 15 février 2010, 2009, consulté le 11 février 2017. Disponivel em: <http://geocarrefour. revues.org/7598>.

JOSEPH, C. L. Ameaça para a Integridade territorial da Guiana, s/d. [En ligne], Disponivel em: <http://www.guyana. org/features/territorial_integrity.html>, consulté le 5 octobre 2014.

LEVI, W. Contemporary International Law: A Concise Introduction, second edition, Boulder, $\mathrm{CO}$, Westview Press, 1991.

LÉZY, E. Guyane-Guyanes, une géographie sauvage de l'Orénoque à l'Amazone, Paris, Belin, 2000.

MARTÍNEZ, M. V. Venezuela y Guyana: Bilateralidad y Fronteras, in: Porto, J. L. R., Sotta, E. D. (Orgs.), Reformatações Fronteiriças no Platô das Guianas: (re) territorialidades de cooperações em construção. Rio de Janeiro: Publit, 2011.

MENCK, J. T. M. A Questão do Rio Pirara (1829-1904), Brasília, Funag, 2009.

NIMOS (National Institute for Environment and Development in Suriname), Suriname's: First National Communication to the United Nations Framework Convention on Climate Change, Paramaribo, Sappi, 2005.

ONU (Organização das Nações Unidas), Convention des Nations unies sur le droit de la mer dite de Montego bay, 1982, [En ligne] Disponível em: <www.ifmer.org/assets/ documents/files/...ifm/documents-convention-droitmer.pdf >. consultée le 12 février 2017.

PAÚL, I. M. Análisis crítico del problema Fronterizo Venezuela Gran Bretaña), in La Reclamación Venezolana sobre la Guyana Esequiba, Caracas, Ciclo de Conferencias de las Academias Nacional de la Historia y Ciencias Políticas y Sociales, Série Eventos, 1983.

PAÚL, I. M. Los lindes y las fronteras terrestres internacionales, Geovenezuela: Geoestrategia e Integración, n. 9, 2005. p. 26-79. 
Litígios Transfronteiriços na região das Guianas:

questões geopolíticas na interface entre a Amazônia e o Caribe

PNUD (Programa das Nações Unidas para o Desenvolvimento), Guiana Shield Facility supports sustainable development, [En ligne], Disponivel em: <http://www.gy.undp.org/content/guyana/en/home/ operations/projects/environment_and_energy/project_ sample2.html>, Consulté le 4 décembre 2014.

PORTO, J.L.R. ; SILVA, G.V. Novos usos e (re)construções da condição fronteiriça amapaense, Belém, Revista Novos Cadernos NAEA. v. 12, n. 2, 2009. p. 253-267.

POUYLLAU M. et D. Géopolitique et géostratégies du Venezuela, Hérodote $n^{\circ} 27,4^{\text {ème }}$ trimestre, Paris, 1982. p. 125-153.

PROCÓPIO, A. A Amazônia Caribenha, Revista Brasileira de Política Internacional, v 50, n 2, 2007. p. 97-117.

RAEYMAEKERS, T. The silent encroachment of the frontier: A politics of transborder trade in the Semliki Valley (Congo-Uganda), Political Geography, v 28, 2009. p. 55- 65.

RAMRAJ, R., Guyana's Border Disputes with Venezuela and Suriname, The Geographical Bulletin, V. 44, n. 1, 2002. p. 51-59.

ROPER, S. Cross-border and local co-operation on the island of Ireland: An economic perspective, Political Geography, 26. 2007. p. 554-574.

SANGUIN, A-L. Les nouvelles perspectives frontalières de l'Union Européenne après l'élargissement de 2004, L'Espace Politique, [En ligne], 1 | 2007-1, 2007, mis en ligne le 16 janvier 2007, consulté le 12 février 2017. Disponivel em: 〈http://espacepolitique.revues.org/437>.

SILVA, G.V. Interações espaciais Amapá (BR)-Guiana Francesa (FR). Uso político do território e cooperação transfronteiriça, in Porto, J.L.R., Nascimento, D. M. Interações fronteiriças no Platô das Guianas: novas construções, novas territorialidades, Rio de Janeiro, Publit., 2010. pp. 75-106.

SILVA, G.V, A Cooperação Transfronteiriça entre Brasil e França: Ensaios e Expectativas neste século XXI. Tese de Doutorado, Rio de Janeiro, Programa de Pós-Graduação em Geografia da Universidade Federal do Rio de Janeiro (PPGG-UFRJ), 2013a.

SILVA, G.V. Usos Contemporâneos da Fronteira Franco-
Brasileira: Entre os ditames globais e as articulações locais, Macapá, EDUNIFAP, 2013b.

SOUZA, J. M. Mar territorial, zona econômica exclusiva ou plataforma continental?, Revista Brasileira de Geografia, vol.17, 1999. p. 79-82.

SURINAME, 2010, Suriname Investment Guide. Where Business equals Quality of Life. Minister of Trade and Industry, [En ligne] Disponivel em: <http://www.gov.sr/ media/288454/investerings_gids_suriname_aug2010. pdf>. Consulté le 6 décembre 2014.

SURINAME, Second National Communication to the United Nations Framework Convention on Climate Change, 2013, [En ligne] Disponivel em: <http://www.gov. sr/media/1002492/suriname_sncunfc_on_climate_ change_february_2013_-_final_webpreview_v2.3.pdf>. Consulté le 6 décembre 2014.

TAGLIONI, F. ; CRUSE, R. Le Suriname : une île caribéenne comme les autres ?, in Cruse, R. et Rhiney, K. (dir.), Caribbean Atlas, 2011, [En ligne] Disponivel em: <http:// www.atlas-caraibe.fr/thematiques/qu-est-ce-que-lacaraibe/le-suriname-une-ile-caribeenne-comme-lesautres.html>. Consulté le 7 avril 2012.

TANAKA, Y. L'arbitrage Guyana/Suriname : un commentaire, Hague Justice Journal/Journal Judiciaire de La Haye, vol. 2 $\mathrm{n}^{\circ} 3$, 2007. p. 30-36. [En ligne] Disponivel em: <http:// www.haguejusticeportal.net/Docs/HJJ-JJH/Vol_2(3)/ Tanaka\%20Guyana-Suriname\%20FR.pdf>. Consulté le 24 juin 2015.

União Europeia, Objectif Coopération Territoriale européenne 2007-2013, Programme de Coopération transfrontalière "Amazonie » Guyane-Brésil-Surinam, programme opérationnel, Bruxelles, 2007. 228 p.

VAN LIER, R. A. J. Sociedade de Fronteira: uma análise social da história do Suriname, Brasília, Funag/IPRI, coleção Países da América do Sul, 2005.

VASQUEZ, J. A. The War Puzzle, Cambridge, Cambridge University Press, 1993.

VENEZUELA, Constitución de la República Bolivariana de Venezuela, Gaceta Oficial de la Republica Bolivariana de Venezuela, Caracas, fev. 2009. Consulta 2014. * As reflexões aqui contidas foram apresentadas no II Congresso Brasileiro de Geografia Política, Geopolítica e Gestão do Território,
realizado na cidade de Natal, em 2016. Este texto foi originalmente publicado em francês. Referência: SILVA, G.V. Litiges transfrontaliers
sur le plateau des Guyanes, enjeux géopolitiques à l'interface des mondes amazoniens et caribéens », L'Espace Politique [En ligne], 31, 2017-
1. <http://espacepolitique.revues.org/4242>. Agradecemos aos editores da revista L'espace Politique por permitirem a reprodução do
presente texto, mesmo sendo em outra língua. O trabalho contou com financiamento da Coordenação de Aperfeiçoamento do Pessoal
de Nível Superior (CAPES), por meio do projeto Transfronteirizações na América do Sul: Dinâmicas Territoriais, Desenvolvimento
Regional, Integração e Defesa nas Fronteiras Meridional e Setentrional do Brasil (Edital nº31/2013 Pró-Defesa/CAPES, código
42001013065P3).

\section{Gutemberg de Vilhena Silva}

Graduação, mestrado e doutorado em Geografia. Realizou Pós-Doutorado na Universidade de São Paulo (USP), em 2015, e na Universidade Sorbonne Nouvelle, Paris 3, em 2016. Experiência na área de Geografia, com ênfase em Geografia Política. Coordena e participa de vários projetos nacionais e internacionais, tendo as fronteiras das Guianas como seu principal objeto de análise. Além disso, tem organizado edições temáticas e revisado textos de revistas geográficas com pesquisas voltadas para Geopolítica e Relações Internacionais. E-mail: bgeografo@gmail.com 